\title{
Erratum to impact of the novel coronavirus (COVID-19) pandemic on sleep
}

\section{Editorial Office}

Journal of Thoracic Disease

Correspondence to: Editorial Office, Journal of Thoracic Disease. Email: jtd@amepc.org.

doi: 10.21037/jtd-2021-001

View this article at: http://dx.doi.org/10.21037/jtd-2021-001

Erratum to: J Thorac Dis 2020;12:S163-75

In the article that appeared on Page S163-S175, Vol 12, Suppl 2 (October 2020) Issue of the fournal of Thoracic Disease (fTD) (1), name of the author Danielle Wasserman was published incorrectly.

[Before] Danielle Wassermann

[After] Danielle Wasserman

The paper should be cited as Cite this article as: Pérez-Carbonell L, Meurling IJ, Wasserman D, Gnoni V, Leschziner G, Weighall A, Ellis J, Durrant S, Hare A, Steier J. Impact of the novel coronavirus (COVID-19) pandemic on sleep. J Thorac Dis 2020;12(Suppl 2):S163-S175. doi: 10.21037/jtd-cus-2020-015.

Click here to view the updated version of the article.

Open Access Statement: This is an Open Access article distributed in accordance with the Creative Commons Attribution-NonCommercialNoDerivs 4.0 International License (CC BY-NC-ND 4.0), which permits the non-commercial replication and distribution of the article with the strict proviso that no changes or edits are made and the original work is properly cited (including links to both the formal publication through the relevant DOI and the license). See: https://creativecommons.org/licenses/by-nc-nd/4.0/.

\section{References}

1. Pérez-Carbonell L, Meurling IJ, Wasserman D, et al. Impact of the novel coronavirus (COVID-19) pandemic on sleep. J Thorac Dis 2020;12:S163-75.

Cite this article as: Editorial Office. Erratum to impact of the novel coronavirus (COVID-19) pandemic on sleep. J Thorac Dis 2021;13(2):1302. doi: 10.21037/jtd-2021-001 